\title{
Implementation and Consequences for the Indonesian Nation After the Ratification of the Kyoto Protocol
}

\author{
Dewa Gede Sudika Mangku \\ sudika.mangku@undiksha.ac.id \\ Universitas Pendidikan Ganesha, Indonesia
}

\begin{abstract}
Climate change is a global phenomenon caused by human activities in the use of fossil fuel energy as well as land-use and forestry activities. These activities are the main source of Greenhouse Gases, especially carbon dioxide, the largest contribution of which comes from industrialized countries. This gas has the ability to absorb heat that comes from solar radiation emitted back by the earth. This absorption has led to warming of the atmosphere or temperature rise and climate change. The aim of the Kyoto Protocol is to stabilize the concentration of greenhouse gases in the atmosphere at a level that does not harm the Earth's climate system. The concentration level of greenhouse gas emissions in the atmosphere is achieved in such a time as to allow ecosystems to adapt to climate change naturally, to ensure food production and enable economic development to be carried out in a sustainable manner. Indonesia as one of the countries that also ratified the Protocol, of course, has consequences for implementing it into its national law. Developing countries are not required to reduce emissions but can do so voluntarily and are asked to implement cleaner and more climate friendly sustainable development. For this reason, developed countries are required to facilitate technology transfer and provide funds for climatefriendly sustainable development programs. Indonesia is in a very vulnerable position to the impacts of climate change on the environment and the life of the Indonesian people.
\end{abstract}

Keywords: greenhouse gases; kyoto protocol; ratification; international treaties.

\section{Introduction}

Climate change is a global phenomenon caused by human activities in the use of fossil fuel energy as well as land-use and forestry activities. These activities are the main source of Greenhouse Gases (GHG), especially carbon dioxide (CO2), the largest contribution from which comes from industrialized countries. This gas has the ability to absorb heat that comes from solar radiation emitted back by the earth. This absorption has caused atmospheric warming or temperature rise and climate change [1].

Industrialized countries have long produced large amounts of GHG emissions that accumulate in the atmosphere [2][3]. Therefore, it is very reasonable if they are obliged to reduce GHG emissions and address the impacts of climate change. Meanwhile, developing countries that are not obliged to reduce GHG emissions are entitled to assistance from industrialized countries in order to participate voluntarily in reducing GHG emissions and overcoming the impacts of climate change [4].

The Kyoto Protocol on the United Nations Framework Convention on Climate Change regulates the reduction of GHG emissions due to human activities so as to stabilize GHG concentrations in the atmosphere and not harm the earth's climate system. The Kyoto Protocol [5] establishes rules regarding procedures, targets, emission reduction mechanisms, institutions, as well as compliance and dispute resolution procedures [6]. 
As a developing country that is developing, Indonesia needs to accelerate the development of industry and transportation with low emission levels through the use of clean and efficient technology and the use of renewable energy. In addition [7], Indonesia needs to increase the ability of land and forests to absorb GHGs. The Kyoto Protocol guarantees that technology to be transferred to developing countries must meet these criteria through the Clean Development Mechanism). (CDM) governed by the Kyoto Protocol [8].

Global warming causes irregular global climate change and has an impact on the environment as a whole. Indonesia is a developing country that also feels the impact of global warming due to industrial activities from developed countries [9]. Therefore, Indonesia together with other countries also support the existence of the Kyoto Protocol through act of ratification Indonesia ratified the Kyoto Protocol through Law Number 17 of 2004 concerning Ratification of the Kyoto Protocol on the United Nations Framework Convention on Climate Change [10].

The Kyoto Protocol is an international agreement made to overcome the global warming that has an impact on all countries in the world, including Indonesia, who are aware of the importance of the presence of this agreement. Therefore, the government has a duty to pay attention to a good and healthy living environment for its citizens, including the air environment [11].

This convention then divides countries into 2 groups, namely developed countries that are listed in Annex I (known as Annex I countries) and developing countries that are not listed in Annex I countries (known as non-Annex I countries). [12] In the Climate Change Convention it is stated that both Annex I and non-Annex I countries must submit reports known as National Communications, namely reports on emissions inventories. GHG and its national climate change programs and policies.

The Kyoto Protocol is an agreement in the United Nations Framework Session on Climate Change (UNFCCC), which is accepted worldwide on global warming. Countries that cooperate to implement this protocol in their respective countries commit to reduce the release of carbon dioxide gas and five other greenhouse gases, or cooperate in trading gas exemption contracts if they maintain the amount or increase the release of these gases, which is a peak. global warming symptoms.

\section{Discussion}

The Kyoto Protocol is implemented into Indonesia's positive legal regulations through the Law of the Republic of Indonesia Number 17 of 2004 concerning Ratification of the Kyoto Protocol to The United Nations Framework convention on Climate Change (Kyoto Protocol on the United Nations Framework Convention on Climate Change) [13] As a result of the implementation of the Kyoto Protocol into the Indonesian national law, it obliges the Indonesian government to implement every substance of the Kyoto Protocol [14] into the rules of life, especially for the air environment. Even though Indonesia is It is not a country that is obliged to reduce greenhouse gas emissions, but Indonesia can still implement the benefits of ratifying the Kyoto Protocol for Annex 2 countries, namely carrying out environmentally sustainable development and participating in implementing clean development mechanisms [15]. The ratification is also mem have an implementation impact on law and politics, business, and institutions. However, although structurally it has ratified the Kyoto Protocol, in its implementation in the field the elements of the air environment are often ignored [16].

The Kyoto Protocol defines several institutional Conventions and Protocols, including the Conference of the Parties (COP) and the Intergovernmental Panel on Climate Change (IPCC) and their functions in implementing the Conventions and Protocols. It also stipulates 
that the Parties to Annex I of the Convention (industrialized countries, including Russia and other Eastern European countries whose economies are in transition to a free market) are obliged to reduce emissions in accordance with Annex B.

Article 2 of the Kyoto Protocol stipulates the policies and procedures for achieving emission limitation and reduction commitments by countries in Annex I and the obligation to achieve the deadline for these commitments. In addition, the Protocol also requires industrialized countries to implement policies and take action to minimize the adverse impacts of climate change on other parties, especially developing countries[17][3][18][19].

Ideas and programs to reduce GHG emissions internationally have been carried out since 1979. The program gave rise to an idea in the form of an international agreement, namely the Climate Change Convention, which was adopted on May 14, 1992 and entered into force on March 21, 1994. The Indonesian government also signed the agreement and has ratified it through Law Number 6 of 1994. In order for the Convention to be implemented by the Parties, it is deemed important to have a continued commitment, especially for countries in Annex I (industrialized countries or GHG producing countries) to reduce GHGs as the main element causing change climate.

Emission reduction targets known as Quantified Emission Limitations and Reduction Objectives (QELROs) described in Articles 3 and 4 of the Kyoto Protocol are the main provisions of the Kyoto Protocol. GHG emissions according to Annex A of the Kyoto Protocol include: Carbon Dioxide (CO2), Methane (CH4), Nitrous Oxide (N2O), Hydrofluorocarbon (HFC), Perfluorocarbon (PFC), and Sulfurhexafluoride (SF6). GHG emission reduction targets for countries in Annex I of the Convention are regulated in Annex B of the Kyoto Protocol. This provision is a binding article for the state in Annex I.

Article 12 of the Kyoto Protocol outlines procedures for reducing GHG emissions in the framework of cooperation between industrialized countries and developing countries. This mechanism is expected to help Annex I countries achieve emission reduction targets and nonAnnex I countries can implement sustainable development programs. The trick is for Annex I countries to invest in emission reduction programs or programs that have the potential to reduce emissions and/or absorb GHGs in developing countries. The results will be calculated as emission reductions in the Annex I country making the investment. This mechanism involves various requirements and is overseen by an operational body (Executive Board) appointed by the COP. In practice, CDM is purely an emission trading business.

Before ratifying the Kyoto Protocol, Indonesia had an environmental policy called AMDAL. Environmental Policy and the Kyoto Protocol have encouraged Indonesia as an archipelagic country that is vulnerable to the impacts of climate change to formulate environmental policies by carrying out mitigation and adaptation agendas. The mitigation agenda carried out by the Government of Indonesia concerns: 1. Energy conservation 2. Transportation sector 3. Industry sector 4. Application of environmentally friendly technology in the power generation sector 5. Use of new and renewable energy such as the use of solar, wind, wave, geothermal energy and the utilization of rubbish.

Meanwhile, the adaptation agenda in the planned development strategy is carried out through: 1. Climate-related disaster risk reduction program through reforestation programs, reforestation, especially in critical forest/land areas. 2. Dissemination of information on climate change and adaptation information 3. Capacity building for integrating climate change into planning, infrastructure design, conflict management and distribution of groundwater areas for water management institutions 4. Mainstreaming climate change adaptation into policies and programs with a focus on disaster management, water resources, agriculture, health and industry 5. Development of climate change issues into secondary school and university 
curricula; Indonesia's policy to ratify the Kyoto Protocol gives Indonesia an opportunity economically as a non-Annex 1 country through the implementation of the CDM (Clean Development Mechanism) project.

$\mathrm{CDM}$ is a Kyoto Protocol mechanism that allows Annex-I countries and developing countries to work together for "clean development". With the CDM facility, Annex-I countries can fulfill their emission reduction obligations by undertaking "emissions reduction" projects in a developing country and developing countries receive financial and technological compensation from the cooperation. The purpose of CDM as affirmed by the Kyoto Protocol (Article 12) is to help developing countries undertake sustainable development and contribute to the achievement of global emission reduction goals, as well as to help Annex-I countries achieve their emission reduction targets. Annex-I country investments in developing countries that result in emission reductions will be certified and credits for these "certified emission reductions" (CER) will be given to Annex-I countries [20].

However, given the weak commitment of the Parties to the Climate Change Convention, the Conference of the Parties (COP) III held in Kyoto in December 1997 resulted in the Kyoto Protocol agreement which regulates and legally binds industrialized country Parties to implement GHG emission reduction efforts that are can be done individually or together. The Kyoto Protocol aims to keep GHG concentrations in the atmosphere at levels that do not harm the Earth's climate system. To achieve this goal, the Protocol regulates the implementation of emission reductions by industrialized countries by $5 \%$ below 1990 emission levels in the 20082012 period through Joint Implementation, Emission Trading and Clean Development Mechanisms. mechanisms).

By ratifying the Kyoto Protocol [21], Indonesia adopts the Protocol as a national law to be elaborated in a regulatory and institutional framework so that it can: a. reinforce commitment to the Climate Change Convention based on the common but differentiated responsibilities principle; b. carry out sustainable development in particular to maintain the stability of GHG concentrations in the atmosphere so as not to endanger the earth's climate; c. open new investment opportunities from industrialized countries to Indonesia through CDM; d. encourage cooperation with industrialized countries through CDM in order to improve and strengthen capacity, law, institutions, and transfer of GHG emission reduction technology; e. accelerate the development of industry and transportation with low emission levels through the use of clean and efficient technology and the use of renewable energy; f. increase the ability of forests and land to absorb GHGs [22].

The consequence of Indonesia ratifying an international instrument in this case the Kyoto Protocol is the harmonization of the Kyoto Protocol into Indonesian national laws. 32 of 2009 concerning the Protection and Management of the Environment [23] the implementation mechanism of the Kyoto Protocol clearly describes the direction and implementation [2][19][24][25]. The mechanism for implementing the contents of the Protocol contained in Article 15 which reads as follows: 1 . The government and local governments are obliged to make a KLHS to ensure that the principles of sustainable development have become the basis and are integrated in the development of a region and/or policies, plans, and/or programs. 2. The government and local governments are required to implement the KLHS as referred to in paragraph (1) in the preparation or evaluation of: a. regional spatial plan (RTRW) and its detailed plans, long-term development plans (RPJP), and national, provincial, and medium-term development plans (RPJM), and b. policies, plans, and/or programs that have the potential to cause environmental impacts and/or risks. 3. KLHS is implemented with the following mechanisms: a. assessment of the influence of policies, plans, and/or programs on environmental conditions in an area; b. formulation of alternative improvements to policies, 
plans, and/or programs; c. recommendations for improvement for decision making in policies, plans, and/or programs that integrate the principles of sustainable development.

Although not all of the provisions contained in the protocol can be harmonized into national law, Indonesia as a party to the convention has a fairly good role in responding to efforts to save and preserve the environment. The expiration of the agreed deadline for the implementation of the Kyoto Protocol in 2012 yesterday, and the emergence of REDD (Reducing Emissions for Degradation Deforestation) provisions as a continuation of the protocol did not prevent Indonesia from making efforts to reduce emissions. Indonesia remains committed to efforts to reduce emissions and reduce the rate of greenhouse gases through policies, including fuel management, migration of fuel oil to gas fuels, permits for business establishments and building based on AMDAL, stopping imports of equipment/products made from Freon or CFCs. (Chloroflourocarbon) which causes damage to the earth's ozone layer and other policies related to efforts to save the environment.

\section{Conclusion}

The Kyoto Protocol is a legal instrument designed to implement the Climate Change Convention which aims to stabilize GHG concentrations so as not to disturb the Earth's climate system. Indonesia as one of the countries that ratified the protocol carried out harmonization as a form of implementation of the contents of the protocol through Law no. 32 of 2009 concerning Environmental Protection and Management. Environmental Policy and the Kyoto Protocol have encouraged Indonesia as an archipelagic country that is vulnerable to the impacts of climate change to formulate environmental policies by carrying out mitigation and adaptation agendas. The mitigation agenda carried out by the Government of Indonesia concerns energy conservation, the transportation sector in the industrial sector, the application of environmentally friendly technologies in the power generation sector, the use of new and renewable energy such as the use of solar, wind, wave, geothermal energy and waste utilization. The implementation commitment of the Kyoto Protocol is very simple, namely reducing greenhouse gas emissions and increasing greenhouse gas absorption capacity. In addition, the government has set a target of reducing emissions by $26 \%$ with its own efforts and $41 \%$ with international assistance, and the government is also committed to developing forests by not burning and conserving forests. The laws and regulations related to the implementation of the Kyoto Protocol are not contained in government legislation, although the government has made legal products related to forests, these regulations are not intended and indicated to implement the Kyoto Protocol in Indonesia.

\section{References}

[1] D. Murdiyarso, "Implications of the Kyoto Protocol: Indonesia's perspective," Int. Rev. Environ. Strateg., vol. 5, no. 1, pp. 145-156, 2004.

[2] D. G. Purwanto, H., \& Mangku, "Legal Instrument of the Republic of Indonesia on Border Management Using the Perspective of Archipelagic State," Int. J. Business, Econ. Law, vol. 11, no. 4, 2016.

[3] D. G. S. Mangku, "Suatu Kajian Umum tentang Penyelesaian Sengketa Internasional Termasuk di Dalam Tubuh ASEAN," Perspektif, vol. 17, no. 3, 2012.

[4] N. Maskun, M., Napang, M., Naswar, N., Achmad, A., Susyanti Nur, S., \& Habaib AlMukaramah, "COMMITMENT TO REDUCE CONCENTRATION OF GREENHOUSE GASES: INTERNATIONAL RULES AND STATE PRACTICES,” 
A multifaceted Rev. J. F. pharmacy., 2020.

[5] P. R. A. Malik, F., Abduladjid, S., Mangku, D. G. S., Yuliartini, N. P. R., Wirawan, I. G. M. A. S., \& Mahendra, "Legal Protection for People with Disabilities in the Perspective of Human Rights in Indonesia," Int. J. Criminol. Sociol., vol. 10, pp. 538 547, 2021.

[6] C. Böhringer, "The Kyoto protocol: a review and perspectives," Oxford Rev. Econ. Policy, vol. 19, no. 3, pp. 451-466, 2003.

[7] J. Von Stein, "The international law and politics of climate change: Ratification of the United Nations Framework Convention and the Kyoto Protocol," J. Conflict Resolut., vol. 52, no. 2, pp. 243-268, 2008.

[8] M. Zahran, S., Kim, E., Chen, X., \& Lubell, "Ecological development and global climate change: A cross-national study of Kyoto Protocol ratification," Soc. Nat. Resour., vol. 20, no. 1, pp. 37-35, 2007.

[9] K. Iwata, H., \& Okada, "Greenhouse gas emissions and the role of the Kyoto Protocol.," Environ. Econ. Policy Stud., vol. 16, no. 4, pp. 325-342, 2014.

[10] B. Freedman, M., \& Jaggi, "Global warming disclosures: impact of Kyoto protocol across countries,” J. Int. Financ. Manag. Account., vol. 22, no. 1, pp. 46-90, 2011.

[11] G. Aichele, R., \& Felbermayr, "The effect of the Kyoto Protocol on carbon emissions.," J. Policy Anal. Manag., vol. 32, no. 4, pp. 731-757, 2013.

[12] S. Hovi, J., Skodvin, T., \& Andresen, "The persistence of the Kyoto Protocol: why other Annex I countries move on without the United States," Glob. Environ. Polit., vol. 3, no. 4, pp. 1-23, 2003.

[13] I. Grunewald, N., \& Martinez-Zarzoso, "Did the Kyoto Protocol fail? An evaluation of the effect of the Kyoto Protocol on CO2 emissions," Environ. Dev. Econ., vol. 21, no. 1, pp. 1-22, 2016.

[14] T. Walker, S., Hipel, K. W., \& Inohara, "Strategic analysis of the Kyoto protocol," in International Conference on Systems, Man and Cybernetics, 2007.

[15] D. L. Li, H., Berrens, R. P., Bohara, A. K., Jenkins-Smith, H. C., Silva, C. L., \& Weimer, "Would developing country commitments affect US households' support for a modified Kyoto Protocol?," Ecol. Econ., vol. 48, no. 3, pp. 329-343, 2004.

[16] C. Böhringer, C., \& Vogt, "The dismantling of a breakthrough: the Kyoto Protocol as symbolic policy," Eur. J. Polit. Econ., vol. 20, no. 3, pp. 597-617, 2004.

[17] D. G. S. Mangku, "Pelanggaran terhadap Hak Kekebalan Diplomatik (Studi Kasus Penyadapan Kedutaan Besar Republik Indonesia (KBRI) di Yangon Myanmar berdasarkan Konvensi Wina 1961)," Perspektif, vol. 15, no. 3, 2010.

[18] D. G. S. Mangku, "Implementation Of Technical Sub Committee Border Demarcation And Regulation (TSC-BDR) Agreement Between Indonesia-Timor Leste In The Resolution Of The Land Border Dispute," J. IUS Kaji. Huk. dan Keadilan, vol. 8, no. 3, pp. 405-419, 2020.

[19] D. G. S. Purwendah, E. K., \& Mangku, "The Implementation Of Agreement On Transboundary Haze Pollution In The Southeast Asia Region For Asean Member Countries.," Int. J. Business, Econ. Law, vol. 17, no. 4, 2018.

[20] M. Widayanti, I. G. A. S., Mangku, D. G. S., SH, L. M., Yuliartini, N. P. R., \& SH, "Penggunaan Tentara Anak Dalam Konflik Bersenjata Ditinjau Dari Perspektif Hukum Humaniter (Studi Kasus: Konflik Bersenjata Di Sri Lanka)," J. Komunitas Yust., vol. 2, no. $1,2019$.

[21] N. P. R. Sakti, L. S., Mangku, D. G. S., \& Yuliartini, “Tanggung Jawab Negara Terhadap Pencemaran Lingkungan Laut Akibat Tumpahan Minyak Di Laut Perbatasan 
Indonesia Dengan Singapura Menurut Hukum Laut Internasional,' J. Komunitas Yust., vol. 2, no. 3, pp. 131-140, 2020.

[22] E. R. Itasari, "Border Management Between Indonesia And Malaysia In Increasing The Economy In Both Border Areas,” J. Komun. Huk., vol. 6, no. 1, pp. 219-227, 2020.

[23] N. P. R. Wiratmaja, I. G. N. A., Mangku, D. G. S., \& Yuliartini, "Penyelesaian Sengketa Maritime Boundary Delimitation Di Laut Karibia Dan Samudera Pasifik Antara Costa Rica Dan Nicaragua Melalui Mahkamah Internasional," J. Komunitas Yust., vol. 21, no. 1, pp. 60-69, 2020.

[24] A. Purwendah, E., Mangku, D., \& Periani, "Dispute Settlements of Oil Spills in the Sea Towards Sea Environment Pollution," in In First International Conference on Progressive Civil Society (ICONPROCS 2019), 2019.

[25] D. G. S. Itasari, E. R., \& Mangku, "Elaborasi Urgensi Dan Konsekuensi Atas Kebijakan Asean Dalam Memelihara Stabilitas Kawasan Di Laut Cina Selatan Secara Kolektif," Harmony, vol. 5, no. 2, pp. 143-154, 2020. 